\title{
IN MEMORIAM \\ RT HON LORD BINGHAM OF CORNHILL KG
}

13 October 1933-11 September 2010

In his public life Lord Bingham, who has died after several months of illness, was a towering figure in the law. The first person to hold all three senior judicial positions as Master of the Rolls, Lord Chief Justice of England and Wales and Senior Lord of Appeal in Ordinary, he had an immense influence on the development of the law and, as one of the principal architects of the United Kingdom's new Supreme Court, of its institutions. His many obituarists have been reaching for superlatives, describing him as the greatest judge of modern times, defender of liberty, a man of exceptional brilliance and principle.

For the British Institute of International and Comparative Law, it has been an immeasurable privilege to have him, successively, as Chairman of the Council of Management, Chairman of the Institute and, following the retirement of Lord Goff of Chieveley, as our President. In these roles, and especially since his retirement from judicial office, Tom Bingham reached beyond the role of a public figure to bring a real personal commitment to our work. The clarity, breadth and rigour of his thinking, his wisdom, kindness and humanity, coupled with his acute sense of humour, have all contributed to the deep and lasting impression he has made on the life of the Institute. His profound understanding of the importance of international law and of the rule of law in a fast-changing world has been very influential, both within the Institute and much more widely. He was characteristically modest about the Institute's decision to set up the Bingham Centre for the Rule of Law in his honour and, once persuaded of the Institute's commitment to the Centre, was enthusiastically supportive of it. We hope that the Centre will go on to be a fitting and lasting tribute to the memory of this incomparable man.

Alexander Layton QC Chairman, Board of Trustees of the British Institute of International and Comparative Law 